DEPARTMENT OF THE INTERIOR

U.S. GEOLOGICAL SURVEY

\title{
GEOLOGIC MAP AND COAL STRATIGRAPHY OF THE NEEDLE EYE POINT QUADRANGLE, KANE COUNTY, UTAH
}

By H. D. Zeller 